\title{
FIXED-DOSE COMBINATION VERSUS SEPARATE ANTITUBERCULOSIS FORMULATIONS IN PULMONARY TUBERCULOSIS PATIENTS: EVALUATION OF EFFECTIVENESS AND SAFETY
}

\author{
RIMENDA SITEPU ${ }^{1}$, PURWANTYASTUTI ASCOBAT ${ }^{1}$, FLORA EKASARI ${ }^{2}$, INSTI INSTIATY ${ }^{*}$ \\ ${ }^{1}$ Department of Pharmacology and Therapeutics, Faculty of Medicine, Universitas Indonesia, Jakarta 10430, Indonesia, ${ }^{2}$ Department of \\ Pulmonology, Dr. Esnawan Antariksa Hospital, Halim Perdana Kusuma, 13610, Jakarta, Indonesia. Email: instiaty@yahoo.com
}

Received: 06 August 2018, Revised and Accepted: November 2018

\section{ABSTRACT}

Objective: This study aimed to compare the effectiveness and safety of fixed dose combination (FDC) versus separate (separate formulation [SF]) antituberculosis (TB) formulations in patients with bacteriologically confirmed pulmonary TB.

Methods: Data were collected retrospectively from patient records, which included all newly diagnosed bacteriologically confirmed pulmonary TB patients treated with first category FDC or SF between January 2014 and January 2017 at the Dr. Esnawan Antariksa Hospital. The efficacy of the formulations was determined according to acid-fast bacilli (AFB) sputum smear conversion at the end of the intensive phase (month 2), after 6 months of therapy, and after the extended treatment phase (month 3). Adverse drug reactions (ADRs) during treatments were recorded as safety outcomes. Chi-square tests were used to analyze the differences between the groups.

Results: On comparing patients treated with FDC ( $\mathrm{n}=33)$ and SF $(\mathrm{n}=30)$, rates of sputum conversions did not differ significantly after 2 months (83.3\% vs. $78.7 \%, p=0.693$ ) and the intensive phase was extended by 1 month for patients with conversion failures at this time point. One of seven patients in the FDC group did not achieve sputum conversion during the extended phase and was recorded as a medication failure. At the end of continuation phase, all other subjects achieved sputum conversion. The overall frequencies of ADRs were not significantly higher in the FDC group than that in the SF group (36.4\% vs. $23.3 \%$, $\mathrm{p}=0.260)$.

Conclusion: No differences in effectiveness and safety profiles were identified between first category FDC and separate anti TB formulations.

Keywords: Tuberculosis, Fixed-dose combination, Separate antituberculosis formulations, Sputum conversion.

(C) 2018 The Authors. Published by Innovare Academic Sciences Pvt Ltd. This is an open access article under the CC BY license (http://creativecommons. org/licenses/by/4. 0/) DOI: http://dx.doi.org/10.22159/ijap.2018.v10s1.46

\section{INTRODUCTION}

According to the global tuberculosis (TB) Report, 2014, from the World Health Organization, TB affected 9.6 million patients globally and caused mortality in 1.2 million patients. India, Indonesia, and China had the highest numbers of TB patients, representing $23 \%, 10 \%$, and $10 \%$ of all patients, respectively [1]. The Global TB Report 2014 also states that 5.4 million new cases of TB were confirmed in bacteriological studies, and 0.3 million of these were relapse cases that had previously been cured. The percentage relapse rates among TB patients were 33\% in India, 9\% in China, 5.3\% in South Africa, 5\% in Russia, and 2.6\% in Indonesia [1,2].

Pulmonary TB was confirmed in 330,910 cases in Indonesia during 2015 and was higher than in the previous year $(324,538$ cases) [3]. In Jakarta, 24,500 cases were identified during 2012, corresponding with a prevalence rate of 256 per 100,000 people, and the Case Fatality Rate was 2 per 100,000 people living in Jakarta [3].

The relative efficacies of fixed-dose combination (FDC) and separate formulation (SF) anti TB therapies remain questionable. In a study during 2011, Lienhardt et al. showed that FDC and FC had similar effectiveness, but patient compliance was better in the FDC group [4]. Aseffa et al. 2016 also confirmed that FDC and SF were equally effective as cures for pulmonary TB [5], and in an Indonesian study by Tabrani and Sputum 2007, no differences in AFB sputum conversion were found between FDC and SF groups at the end of the intensive phase. However, no published trials compare AFB sputum conversion during the continuation phase [6].

In 2003, Immanuel et al. stated that the bioavailability of rifampicin was decreased when administered concomitantly with other anti-
TB agents [7]. Singh et al. also showed decreases in rifampicin bioavailability following formulation into tablets with isoniazid [8].

In an Indonesian study conducted by van Crevel et al. during 2002, 62 TB patients were prescribed with the anti-TB agent 2RHZE at doses of $450,300,1500$, and $750 \mathrm{mg}$ during the intensive phase and continued with $4 \mathrm{R} 3 \mathrm{H} 3$ at $450-$ and $600-\mathrm{mg}$ doses during the continuation phase. These investigators reported a $70 \%$ decrease in the rifampicin plasma concentrations, resulting in subtherapeutic plasma levels of $<4 \mathrm{mg} / \mathrm{L}$ [9]. In a study conducted in South Sulawesi by Suryanto et al. during 2008, the incidence of pulmonary TB relapse after successful FDC treatments remained higher (10.1\%) than that after successful SF treatments $(2.7 \%)[10]$.

There remains a lack of information about differences in effectiveness and safety of FDC and SF during intensive and continuation phases in Indonesia. Thus, we evaluated effectiveness and safety in FDC SF treatment groups of patients with bacteriological confirmed pulmonary TB during January 2014-January 2017 at the Dr. Esnawan Antariksa hospital in Halim Perdana Kusuma.

\section{METHODS}

\section{Study design}

This retrospective study was conducted using secondary data from the medical records of patients. Bacteriologically confirmed TB patients who were prescribed anti-TB first category FDC or SF between January 2014 and January 2017 were recruited from the Dr. Esnawan Antariksa Hospital at Jakarta. The Ethics Committee of the Faculty of Medicine at Universitas Indonesia approved the study (No: 811/UN2.F1/ ETIK/2017). 
Population and study samples

The data were collected from all the clinical records of new-onset bacteriologically confirmed TB patients who were prescribed first category anti-TB FDC or SF treatments. The included patients were male or female and were 15-75 years old. Excluded from the analyzes were patients with HIV infections, incomplete medical records, extra-pulmonary TB, or multiple TB infections (pulmonary TB and extrapulmonary TB) were excluded from analyses.

\section{Outcomes}

Effectiveness was evaluated according to sputum conversion at the end of the intensive (month 2) and continuation phases (month 6) of therapy. Safety outcomes were the adverse drug reactions (ADRs) that occurred during treatment.

\section{RESULTS AND DISCUSSION}

A total of 125 patients with new-onset pulmonary TB were prescribed first category anti-TB agents, and 75 of these were bacteriologically confirmed. One patient was excluded due to incomplete data, and 11 were excluded because they did not continue treatments at the Dr. Esnawan Antariksa Hospital. The final cohort included 33 patients in the FDC group and 30 patients in the SF group, and treatment groups had similar mean baseline characteristics (Table 1).

Frequencies of sputum conversions at the end of the intensive phase, the extended phase, and the continuation phase are presented in Table 2. Sputum conversion rates at the end of the intensive phase were higher in the SF group (83.3\%) than in the FDC group (78.8\%), but this difference was not significant $(\mathrm{p}=0.693)$. According to the, 2014 , Indonesia National guidelines for TB treatment, the intensive phase was extended for one more month (extended phase) in patients with conversion failure at 2 months. At the end of the extended phase, sputum conversion in the FDC group was $85.7 \%$ and that in the SF group was $100 \%$. One patient in the FDC group did not achieve sputum conversion during the extended phase, and the patient was considered a medication failure, was excluded from the study, and received second category anti-TB treatment. At the end of the continuation phase, all the subjects achieved sputum conversion.

Table 1: Baseline characteristics

\begin{tabular}{|c|c|c|c|}
\hline Characteristic & FDC & SF & $\mathbf{p}$ \\
\hline Total patients - n (\%) & $33(52.4)$ & $30(47.6)$ & \\
\hline \multicolumn{4}{|l|}{ Age - n (\%) } \\
\hline $15-54$ years & $28(84.8)$ & $21(70)$ & \multirow[t]{2}{*}{0.157} \\
\hline 55-74 years & $5(15.2)$ & $9(30)$ & \\
\hline \multicolumn{4}{|l|}{ Sex - n (\%) } \\
\hline Men & $16(48.5)$ & $18(58.6)$ & \multirow[t]{2}{*}{0.360} \\
\hline Women & 17 (51.5) & $12(41.4)$ & \\
\hline \multicolumn{4}{|l|}{ BMI $\left(\mathrm{kg} / \mathrm{m}^{2}\right)-\mathrm{n}(\%)$} \\
\hline Underweight (<18.5) & $2(6.1)$ & $11(37.9)$ & \multirow[t]{4}{*}{0.105} \\
\hline Healthy (18.5-24.9) & $24(72.7)$ & $18(58.6)$ & \\
\hline Overweight (25-26.9) & $3(9.1)$ & $0(0)$ & \\
\hline Obese $(\geq 27)$ & $4(12.1)$ & $1(3.4)$ & \\
\hline \multicolumn{4}{|l|}{ Smoking - n (\%) } \\
\hline Smoker & $33(100)$ & $29(97.0)$ & \\
\hline Non smoker & $0(0)$ & $1(3.0)$ & \\
\hline \multicolumn{4}{|l|}{ AFB initial - $\mathrm{n}(\%)$} \\
\hline+1 & $33(100)$ & $28(93.1)$ & \\
\hline+2 & $0(0)$ & $1(3.4)$ & \\
\hline+3 & $0(0)$ & $1(3.4)$ & \\
\hline \multicolumn{4}{|l|}{ Comorbid - n (\%) } \\
\hline Diabetes mellitus & $6(18.2)$ & $6(20.7)$ & 0.854 \\
\hline Hepatitis & $0(0)$ & $1(3.4)$ & - \\
\hline GI tract disorder & $2(6.1)$ & $3(10.3)$ & 0.662 \\
\hline Allergic reactions & $1(3.0)$ & $0(0)$ & - \\
\hline \multicolumn{4}{|l|}{ Adherence-n (\%) } \\
\hline Adhere & $24(72.7)$ & $20(65.5)$ & 0.601 \\
\hline Non-adhere & $9(27.3)$ & $10(34.5)$ & \\
\hline
\end{tabular}

The safety outcomes were evaluated by comparing the incidence of ADRs in the treatment groups (Table 3). Two major ADRs occurred in the FDC group, and these were a hyper-reactivity reaction and hepatitis. Minor ADRs were abdominal discomfort and nausea (19.4\%), flu-like syndrome $(4.8 \%)$, pruritus $(1.6 \%)$, and paresthesia $(1.6 \%)$. The total frequencies of ADRs did not differ significantly between FDC and SF groups (36.4\% vs. $23.3 \%$, respectively, $\mathrm{p}=0.260$ ).

\section{DISCUSSION}

In this study, 7 patients (21.2\%) in the FDC group and 5 patients $(16.7 \%)$ in the SF group failed to achieve sputum conversion at the end of the intensive phase. After 1-month extensions of the intensive phase (extended phase), all the 5 patients in the SF group achieved conversion, whereas one patient in the FDC group failed. Since there was no data of anti-TB resistance in this patient, we were unable to determine whether the effectiveness of FDC was inferior to that of SF. Similarly, in a 2008 study, Tabrani showed no differences in sputum conversion between FDC and SF groups at the $4^{\text {th }}$ and $8^{\text {th }}$ weeks of treatment [6]. In 2014, Caesar showed higher sputum conversion rates at the end of an intensive phase in the FDC group $(72.72 \%)$ than in the SF group (65.90\%) but failed to show statistical significance $(\mathrm{p}=0.644)$ [11]. Similarly, Lienhardt et al. showed no significant differences in effectiveness and safety between FDC and SF treatment groups in 2011 [12].

Most of the previous studies of TB treatments only report sputum conversion at the end of the intensive phase $[6,11,12]$. In this study, we additionally evaluated sputum conversions at the continuation phase with the intention of resolving questions regarding the effectiveness of intermittent anti-TB regimens during the continuation phase. One of our patients failed to achieve conversion by the end of the extended phase, indicating medication failure, and subsequently received second category anti-TB treatment. In the remaining patients that received treatment during the continuation phase, sputum conversion was maintained to the end of month 6 in both the FDC and the SF groups.

Finally, whereas major ADRs only occurred in the FDC group, the overall frequency of ADRs did not differ significantly between the FDC and SF groups.

Table 2: Sputum conversion rates at the ends of intensive, extended, and continuation phases

\begin{tabular}{llll}
\hline Phase & Sputum conversion & FDC n/N (\%) & SF n/N (\%) \\
\hline Intensive & Conversion & $26 / 33(78.8)$ & $25 / 30(83.3)$ \\
& No conversion & $7 / 33(21.2)$ & $5 / 30(16.7)$ \\
Extended & Conversion & $6 / 7(85.7)$ & $5 / 5(100)$ \\
\multirow{3}{*}{ Continuation } & No conversion & $1 / 7(14.3)^{*}$ & $0.5(0)$ \\
& Conversion & $32 / 32(100)$ & $30 / 30(100)$ \\
& No conversion & $0 / 32(0)$ & $0 / 30(0)$ \\
\hline
\end{tabular}

FDC: Fixed-dose combination, SF: Separate formulation, n: Numbers of patients with or without sputum conversion, $\mathrm{N}$ : total numbers of patients in treatment groups. * One patient was excluded due to conversion failure

Table 3: Frequencies of ADRs in FDC and SF groups

\begin{tabular}{lll}
\hline ADRs & FDC $\mathbf{n = 3 3}$ & SF $\mathbf{n = 3 0}$ \\
\hline Major - n (\%) & $2(6.1)$ & $0(0)$ \\
Hypereactivity reactions & $1(3.0)$ & $0(0)$ \\
Hepatitis & $1(3.0)$ & $0(0)$ \\
Minor - n (\%) & $10(30.3)$ & $0(0)$ \\
Abdominal discomfort & $8(24.2)$ & $7(23.3)$ \\
Pruritus & $0(0)$ & $4(13.3)$ \\
Flu-like syndrome & $2(6.1)$ & $1(3.3)$ \\
Paresthesia & $0(0)$ & $1(3.3)$ \\
Major+minor & $12(36.4)$ & $7(23.3)$ \\
\hline
\end{tabular}

ADRs: Adverse drug reactions, FDC: Fixed-dose combination, SF: Separate

formulation, n: Frequencies of ADRs, N: Total numbers of patients 
The small sample size limited the significance of the differences between treatment groups.

\section{CONCLUSION}

Sputum conversion rates at the end of the intensive phase were higher in the SF group (83.3\%) than in the FDC group (78.8\%), but this difference was not significant $(p=0.693)$. The total frequencies of ADRs did not differ significantly between FDC and SF groups (36.4\% vs. $23.3 \%$, respectively, $\mathrm{p}=0.260$ ). Thus, no significant differences in effectiveness and safety profiles of the first category FDC and SF anti-TB formulations were found in this study, warranting further studies with larger sample sizes

\section{CONFLICTS OF INTEREST}

All authors have none to declare.

\section{REFERENCES}

1. World Health Organization. Global Tuberculosis Report 2014. Available from: http://www.who.int/tb/publications/global report/en. [Last accessed on 2016 Sep 23].

2. World Health Organization. Global Tuberculosis Report 2015. Available from: http://www.who.int/tb/publications/global report/en. [Last accessed on 2016 Sep 23].

3. Department of Health Jakarta. Health Profile of DKI Jakarta Province. Jakarta: PDKI; 2012

4. Lienhardt C, Cook SV, Burgos M, Yorke-Edwards V, Rigouts L, Anyo G, et al. Efficacy and safety of a 4-drug fixed-dose combination regimen compared with separate drugs for treatment of pulmonary tuberculosis: The study C randomized controlled trial. JAMA 2011;305:1415-23.
5. Aseffa A, Chukwu JN, Vahedi M, Aguwa EN, Bedru A, Mebrahtu T, et al. Efficacy and safety of 'fixed dose' versus 'loose' drug regimens for treatment of pulmonary tuberculosis in two high TB-burden African countries: A Randomized controlled trial. PLoS One 2016;11:e0157434.

6. Tabrani I. Sputum BTA Conversion at Intensive Phase of Category I pulmonary TB Between Fixed-Dose Combination and Generic AntiTuberculosis Drug at RSUP H Adam Malik Medan. Thesis. Medan: Universitas Sumatera Utara; 2007.

7. Immanuel $\mathrm{C}$, Gurumurthy $\mathrm{P}$, Ramachandran $\mathrm{G}$, Venkatesan $\mathrm{P}$, Chandrasekaran V, Prabhakar R, et al. Bioavailability of rifampicin following concomitant administration of ethambutol or isoniazid or pyrazinamide or a combination of the three drugs. Indian J Med Res 2003;118:109-14.

8. Singh S, Bhutani H, Mariappan TT. Quality problems of antituberculosis fixed dose combination (FDCs): A way forward. Indian J Tuberc 2006;53:201-5.

9. van Crevel R, Alisjahbana B, de Lange WC, Borst F, Danusantoso H, van der Meer JW, et al. Low plasma concentrations of rifampicin in tuberculosis patients in Indonesia. Int $\mathrm{J}$ Tuberc Lung Dis 2002;6:497-502.

10. Suryanto AA, Van den Broek J, Hatta M, De Soldenhoff R, Van der Werf MJ. Is there an increased risk of TB relapse in patient treats with fixed dose combination drugs in Indonesia? Int $J$ Tuberc Lung Dis 2008;12:174-9.

11. Caesar MD. Comparison Effect of Anti Tuberculosis Fixed Dose Combination and Separate Drug to Sputum Smear Conversion at the end of Intensive Phase to Tuberculosis Patient in Surakarta Community Pulmonary Health Institute. Thesis. Surakarta: Universitas Muhammadiyah Surakarta; 2014

12. Bartacek A, Schütt D, Panosch B, Borek M, Rimstar 4-FDC Study Group. Comparison of a four-drug fixed-dose combination regimen with a single tablet regimen in smear-positive pulmonary tuberculosis. Int J Tuberc Lung Dis 2009;13:760-6. 